\title{
Largest Cross-sectional Thickness
}

National Cancer Institute

\section{Source}

National Cancer Institute. Largest Cross-sectional Thickness. NCI Thesaurus. Code C127567.

The assessment of the largest cross-sectional thickness of a tissue. 